\title{
Motility and Adhesiveness in Human Neutrophils
}

\author{
EFFECTS OF CHEMOTACTIC FACTORS
}

\author{
C. Wayne Smith, James C. Hollers, Richard A. Patrick, and Clare Hassett, \\ Departments of Anatomy and Microbiology and Public Health, \\ Michigan State University, East Lansing, Michigan 48824
}

A B S T RA C T Human peripheral blood neutrophils (PMN) obtained from healthy adults were examined in vitro with techniques adapted to assess the effects of chemotactic factors $(\mathrm{CF})$ on cellular configuration and adhesiveness. The results were compared with those that use certain conventional techniques for assessing chemotaxis and chemokinesis. Exposure of PMN to $\mathrm{N}$ formyl-L-methionyl-L-phenylalanine (f-Met-Phe), zymosan-activated serum, bacterial chemotactic factor, or a low molecular weight chemotactic factor from activated serum (C5a) in the absence of a gradient resulted in a change in cellular shape from a spherical to a polarized configuration in a high percentage of cells. This occurred rapidly in suspension, under conditions designed to exclude a role for cell adhesiveness, and was reversible upon removal of the CF. Restimulation of cells with the CF resulted in reappearance of the polarized configuration to the same extent as on initial stimulation with one exception: f-Met-Phe pretreated cells failed to respond to $\mathrm{f}$-Met-Phe, though they responded fully to the other CF. Each CF caused a significant increase in PMN attachment to proteincoated glass. This enhanced adhesiveness was not reversible upon removal of the CF when the cells were treated under conditions shown to produce chemotactic deactivation. Cells treated under these conditions also exhibited significantly reduced motility on glass and in micropore filters in the absence of a gradient of CF. Bacterial chemotactic factor, even at high concentrations, failed to produce deactivation and did not cause a sustained enhancement of adhesiveness.

\section{INTRODUCTION}

An event which accompanies neutrophil locomotion is attachment to a substratum. Attachment to a surface seems to be a prerequisite for migration in vitro (1) (e.g., to glass or plastic) and in vivo (2) (e.g., to endothelial

Received for publication 14 July 1978 and in revised form 2 October 1978. cells), and has been thought to contribute to the development of the polarized cellular shape assumed by neutrophils during migration in vitro (3). There is considerable evidence to support the idea that the nature of the interaction of some cell types with the substratum in vitro influences translocation $(1,4-6)$. The influence may be on the direction of movement (e.g., haptotaxis) or the rate of movement. The possible influence of the cell-substratum interaction on aspects of neutrophil motility such as cellular polarity, translocation, orientation and migration in a chemotactic gradient, and chemokinesis is unclear at present.

In this report we will examine two aspects of the effects of chemotactic factors $(\mathrm{CF})^{\mathbf{1}}$ on neutrophil motility in vitro: the development of cellular polarity and the enhancement of cell adhesiveness to a substratum. The results indicate that $\mathrm{CF}$ stimulate the development of a bipolar cellular configuration under conditions designed to exclude a role for cell adhesiveness, and that CF can increase neutrophil adhesiveness under conditions where few cells exhibit a bipolar shape. Furthermore, by using assessments of cellular shape and adhesiveness, we were able to obtain results that show a correlation between enhanced adhesiveness and reduced motility in the phenomena of chemotactic deactivation and cross deactivation (7).

\section{METHODS}

Isolation of human neutrophils. Blood samples were obtained from a pool of 15 healthy adult volunteers ( 7 women and $8 \mathrm{men}$ ). Leukocyte-rich plasma was prepared by dextran sedimentation of erythrocytes. The leukocytes were washed one time in Hanks' balanced salt solution (HBSS) to remove the plasma and then separated by centrifugation on Ficoll

${ }^{1}$ Abbreviations used in this paper: $\mathrm{BCF}$, bacterial chemotactic factor; BSA, bovine serum albumin; CF, chemotactic factor(s); CMf HBSS, $\mathrm{Ca}^{++}$- and $\mathrm{Mg}^{++}$-free Hanks' balanced salt solution; DMSO, dimethyl sulfoxide; HBSS, Hanks' balanced salt solution; PMN, peripheral blood neutrophils; ZAP, zymosan-activated plasma; ZAS, zymosan-activated serum. 
(Pharmacia Fine Chemicals Inc., Piscataway, N. J.)-Hypaque (Winthrop Laboratories, New York) cushions (8). The leukocytes used in the following experiments were $>98 \%$ granulocytes, of which $\cong 95 \%$ were neutrophils. No platelets were seen in the preparations, and the erythrocyte (RBC) to peripheral blood neutrophils (PMN) ratio was consistently $<2: 1$. The PMN viability was $>98 \%$ as determined by eosin exclusion.

The PMN were resuspended at $10^{7} / \mathrm{ml}$ in $\mathrm{HBSS}$ and immediately placed at $4^{\circ} \mathrm{C}$. PMN to be evaluated by the techniques described below were drawn from this pool for up to $5 \mathrm{~h}$. No change attributable to incubation at $4^{\circ} \mathrm{C}$ for $5 \mathrm{~h}$ could be detected in any of the parameters of PMN behavior tested.

Assessment of neutrophil motility. Neutrophil motility into micropore filters was tested by a modified Boyden technique with blind-well chambers (Neuro Probe, Inc., Bethesda, Md.) and 3- or 5- $\mu \mathrm{m}$-pore size Millipore filters (Millipore Corp., Bedford, Mass.). The chambers were prepared with $2 \times 10^{4}$ neutrophils $/ \mathrm{mm}^{2}$ of exposed filter surface and CF or control solution placed in the lower well. Incubation was carried out at $37^{\circ} \mathrm{C}$ in an atmosphere of $5 \% \mathrm{CO}_{2}$ and high humidity. The behavior of the neutrophil population in this system was measured in two ways.

(a) The number of neutrophils that had accumulated on the lower surface of the filter was counted after $3 \mathrm{~h}$ of incubation. 10 microscopic fields ( $\times 40$ objective) were counted on each filter, and the averages of duplicate or triplicate determinations in each experiment were recorded.

(b) The depths at which only two cells were in focus in one microscopic field were measured in filters after various incubation times up to $90 \mathrm{~min}$. These values were considered an expression of the penetration of the "leading front" of the population. Measurements were made at five locations in duplicate filters in each experiment.

Motility of neutrophils on glass was tested by a modification of the technique of Harris (9). Neutrophils $\left(2.5 \times 10^{5}\right)$ in HBSS were allowed to settle and adhere to the 25-mm diameter cover slip and then examined under dark-field illumination. Duplicate 10-min time exposures were made with Polaroid type 105 positive/negative film (Polaroid Corp., Cambridge, Mass.). The lengths of all migration tracks photographed were measured on $8-\times 10$-in prints and recorded as arbitrary units based on the approximate final magnification.

Assessment of neutrophil adhesiveness. Slide chambers similar to those reported by Lichtman and Weed (10) were filled with a suspension of PMN $\left(1 \times 10^{6} / \mathrm{ml}\right)$ in HBSS, $10 \%$ plasma, or $2 \%$ bovine serum albumin (BSA) in HBSS. The chambers were immediately placed on the stage of an inverted phase-contrast microscope and observed with a $\times 50$ oilimmersion objective at room temperature. This allowed observations of cells settling onto the glass surface. Between $\mathbf{3 5 0}$ and $500 \mathrm{~s}$ after injecting cells into the chamber, cell counts were made in five randomly selected $\times 50$ fields, and the cells were classified as rounded (spherical) or motile (bipolar shape). The chambers were then inverted for $400 \mathrm{~s}$. The number of cells remaining attached to the glass was assessed by counting five $\times 50$ fields.

Assessment of changes in neutrophil shape. A modification of the method of Lichtman et al. (11) was used. Suspensions of $10^{6} \mathrm{PMN}$ in $1 \mathrm{ml}$ of $\mathrm{HBSS}$ were exposed to the various conditions and reagents described. The $\mathrm{pH}$ was adjusted with $5 \% \mathrm{CO}_{2}$ in air. At the appropriate time, the cell suspension was added dropwise to $10 \mathrm{ml}$ of cold $\left(4^{\circ} \mathrm{C}\right) 1 \%$ glutaraldehyde in $0.1 \mathrm{M}$ cacodylic acid (Sigma Chemical Co., St. Louis, Mo.). The glutaraldehyde solution was mixed constantly while the cells were being added. After remaining in the cold glutaraldehyde solution for $1 \mathrm{~h}$ the cells were washed and resuspended in $0.1 \mathrm{ml}$ of distilled water. The PMN were examined with a $\times 100$ phase-contrast objective and classified according to shape (Fig. 1).

CF. Zymosan-activated plasma (ZAP) or serum (ZAS) was prepared by incubating zymosan (ICN Nutritional Biochemicals Div., International Chemical \& Nuclear Corp., Cleveland, Ohio) $(10 \mathrm{mg} / \mathrm{ml})$ with fresh human plasma or serum for $30 \mathrm{~min}$ at $37^{\circ} \mathrm{C}$, diluting this mixture 10 -fold with HBSS, and then removing the zymosan particules by centrifugation and filtration through a $0.22-\mu \mathrm{m}$-pore size Millipore filter. The ZAP or ZAS was used at this concentration (10\%) in most experiments.

$\mathrm{N}$-formyl-L-methionyl-L-phenylalanine (f-Met-Phe) (12) (Andrulis Research Corp., Bethesda, Md.) was dissolved in HBSS to a concentration of $1 \mathrm{mM}$ and diluted further with HBSS to the desired concentrations.

Bacterial chemotactic factor (BCF) was a generous gift from Dr. Elmer Becker, Department of Pathology, University of Connecticut Medical Center; Farmington, Conn. The preparation was a butanol extract of Escherichia coli-culture media. The material was prepared for use in the current studies by first vacuum-evaporating the butanol and then dissolving the dry BCF in HBSS. Concentrations are expressed as dilutions of the original volume of butanol. Maximum chemotactic activity was found at a 1:2,000 dilution.

A low molecular weight CF was prepared from activated human serum by the method of Gallin and Rosenthal (13). Briefly, human serum was incubated with $0.1 \mathrm{mg} / \mathrm{ml} E$. coli lipopolysaccharide (.026.B6 lipopolysacchride B, Difco Laboratories, Detroit, Mich.) at $37^{\circ} \mathrm{C}$ for $1 \mathrm{~h}$. The serum was then heated at $56^{\circ} \mathrm{C}$ for $30 . \mathrm{min}$. After rapid cooling, the activated serum was layered onto a Sephadex G-75 (Pharmacia Fine Chemicals Inc.) column $(90 \times 5 \mathrm{~cm})$. The column was equilibrated with $\mathrm{Ca}^{++}$- and $\mathrm{Mg}^{++}$-free HBSS (CMf HBSS) at pH 7.4, and the serum fractions were eluted in CMf HBSS by descending flow at $4^{\circ} \mathrm{C}$. The column was calibrated with the following substances: Blue dextran $\left(2 \times 10^{6} \mathrm{~mol} \mathrm{wt}\right)$, cytochrome $C(12,384)$, ribonuclease $A(13,700)$, chymotrypsinogen $(25,000)$, and ovalbumin $(45,000)$. Fractions in the 20,000 to $10,000-\mathrm{mol}$ wt range were assayed in modified Boyden chambers. Those showing chemotactic activity were pooled and frozen at $-70^{\circ} \mathrm{C}$. The pool containing chemotactic activity had $40 \mu \mathrm{g} / \mathrm{ml}$ protein. This reagent will be referred to as C5a and the concentrations of this reagent used in the experiments in this report will be expressed in micrograms of protein per milliliter.

The factors used in the following studies produced chemotactic and chemokinetic responses (14) in the human PMN. ZAS was maximally effective at a $10 \%$ dilution, $\mathrm{f}-\mathrm{Met}-\mathrm{Phe}$ at $1 \mu \mathrm{M}, \mathrm{BCF}$ at a $1: 2,000$ dilution, and C5a at $40 \mu \mathrm{g}$ protein $/ \mathrm{ml}$.

Presentation and analysis of data. In many instances the results of experiments are expressed in terms of percent. The specific derivation of the percentage value will be given for each procedure. The data are expressed in terms of the mean \pm SEM; $n$ represents the number of separate experiments. Each experiment contained duplicate or triplicate determinations. Student's $t$ test was used to assess significance.

\section{RESULTS}

Effects of CF on cell shape. Fig. 1 shows the appearance of PMN fixed in suspension with buffered glutaraldehyde. If kept at room temperature $\left(\cong 22^{\circ} \mathrm{C}\right)$ before fixation, the cells were mostly rounded with a slightly ruffled membrane on a small portion of the 

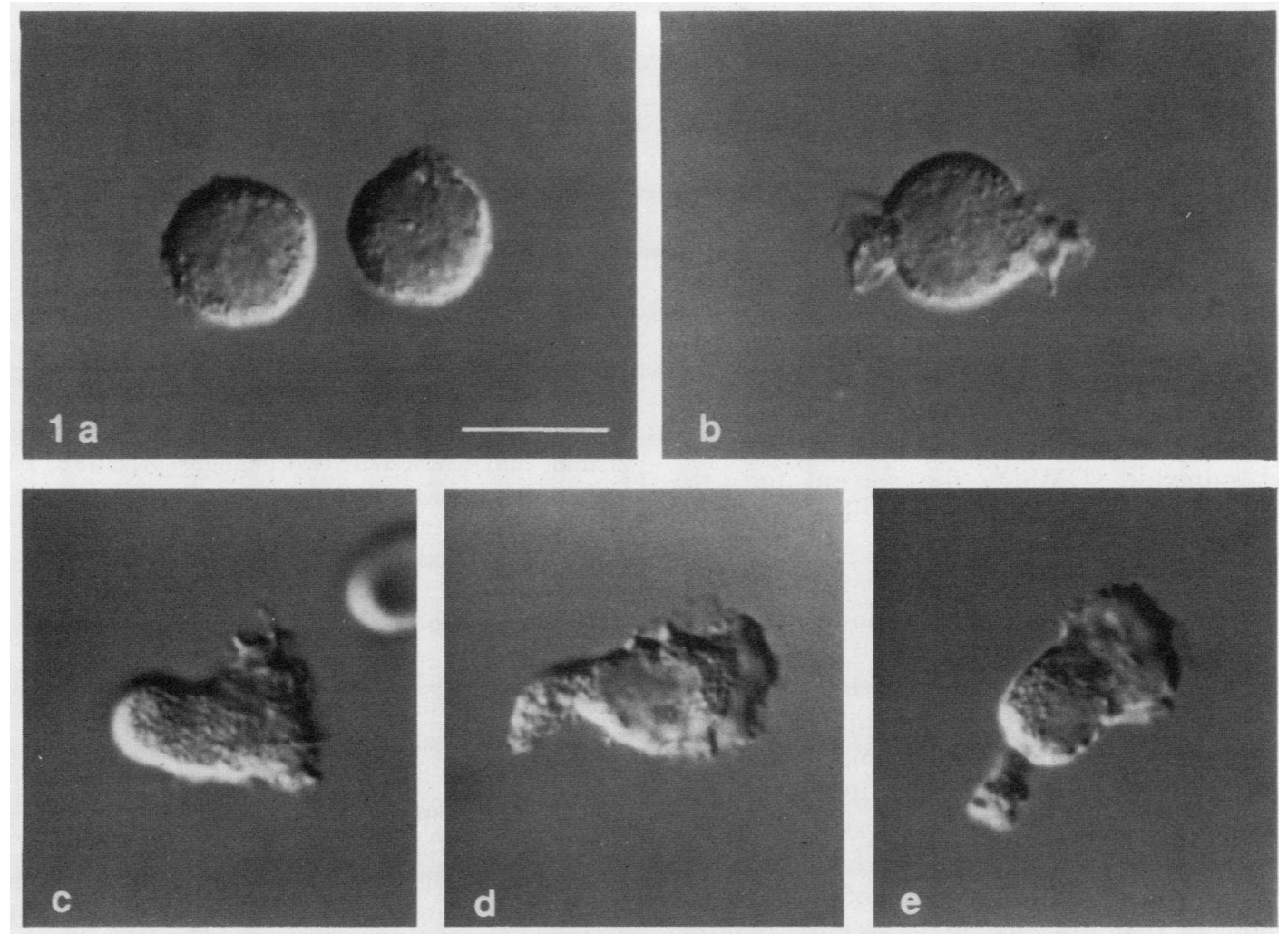

FIGURE 1 Change in shape $(\times 1,600)$ of PMN exposed to CF. The PMN were suspended in HBSS $\left(10^{6} \mathrm{cells} / \mathrm{ml}\right)$ at room temperature and then fixed in suspension in cold $\left(4^{\circ} \mathrm{C}\right)$, buffered glutaraldehyde for $1 \mathrm{~h}$. $a$ and $b$, no CF. $c, d$, and $e, 2$ min after addition of $1 \mu \mathrm{M}$ f-Met-Phe to the cell suspension. Nomarski interference contrast optics.

surface (Fig. $1 a, b)$. The addition of a $\mathrm{CF}$ to the cell suspension resulted in a change in PMN shape. In "double blind" experiments, changes could be detected $30 \mathrm{~s}$ after addition of the CF. By 2 min the cells were more elongated (Fig. $1 c$ ) and many had distinct uropods (Fig. $1 d, e)$. In an effort to quantify this effect of CF on PMN, cells were categorized as spherical or nonspherical. The spherical category included round cells and cells whose shape was generally round with some ruffled membrane. The nonspherical category included cells whose overall form was oval to elongated. Most cells were elongated and appeared distinctly bipolar $10 \mathrm{~min}$ after exposure to a CF. Fig. 2 shows the time course for the change in shape after addition of CF to the PMN suspension.

PMN in HBSS maintained at $4^{\circ} \mathrm{C}$ failed to show significant shape change after addition of CF. PMN in HBSS maintained for $10 \mathrm{~min}$ at $37^{\circ} \mathrm{C}$ showed a higher percentage of cells in the nonspherical category. The response to $\mathrm{CF}$ was slightly higher than at room temperature, and there was a slight tendency for cell aggregation. All subsequent experiments with this technique to assess cellular response to $C F$ were performed at room temperature, as this optimized the dif- ference between control and stimulated PMN suspensions. The addition of BSA at $20 \mathrm{mg} / \mathrm{ml}$ did not affect the cell shape or the change induced by CF. The per-

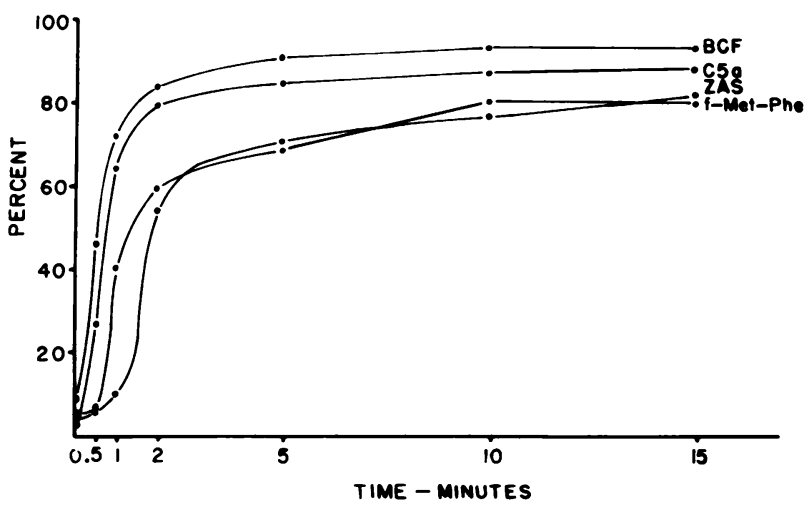

Figure 2 Change in shape of PMN exposed to CF. "Percent" refers to the percent of cells in the suspension with a bipolar shape. "Time-minutes" refers to the time after the addition of the CF. Each point is the mean of two separate experiments. Concentrations of CF added to the cell suspensions: f-Met-Phe, $1 \mu \mathrm{M}$; C5a, $35 \mu \mathrm{g}$ protein $/ \mathrm{ml}$; ZAS, 10\%; BCF, 1:500. 
centage of bipolar forms was not reduced by a 10-fold reduction in cell concentration.

PMN washed twice in CMf HBSS and incubated in CMf HBSS for $30 \mathrm{~min}$ gave the same degree of response to stimulation with the CF as cells in HBSS (e.g., $85.2 \pm 2.5 \%$ with C5a in CMf HBSS, $n=6 ; 88.5 \pm 2.1 \%$ with C5a in HBSS, $n=14)$. EDTA $(1-2 \mathrm{mM})$ added to the PMN suspension in CMf HBSS did not reduce the response.

Pretreatment of PMN with $5 \mu \mathrm{g} / \mathrm{ml}$ of cytochalasin B (Sigma Chemical Co.) for 5 min completely prevented the change in shape after addition of CF (e.g., $1.9 \pm 0.2 \%$ bipolar forms with f-Met-Phe, $n=5$ ). Dimethyl sulfoxide (DMSO), the solvent for cytochalasin B, did not affect cell shape or the response of cells to the CF.

PMN were exposed to the $\mathrm{CF}$ for $30 \mathrm{~min}$ at $37^{\circ} \mathrm{C}$ and then washed in HBSS. After incubation at room tem. perature for 15 and $45 \mathrm{~min}$ in HBSS, the percentage of cells in the nonspherical category was determined. In each case, by $15 \mathrm{~min}$ the cells had significantly fewer nonspherical forms then cell suspensions $10 \mathrm{~min}$ after addition of the CF. For each CF (except BCF), at $15 \mathrm{~min}$ after removal of the $C F$, the percent bipolar forms was $<28(P<0.001)$. BCF-treated cells did not return to this level until $45 \mathrm{~min}$ after removal of BCF. These results indicate that the change in shape is largely reversible upon removal of the stimulant.

Effects of CF on cell adhesiveness. Cells injected into the slide chamber were observed through an inverted phase-contrast microscope. As PMN suspended in HBSS settled onto the lower surface of the chamber, most appeared spherical and essentially the same as cells fixed in suspension (Fig. 1a). Levels of adhesiveness were significantly affected by pretreatment of the cover glass with a solution of BSA or human serum. The exposure of the glass to BSA in HBSS or $5 \%$ human serum in HBSS for 2 min followed by washing in two changes of HBSS reduced attachment (Table I) when compared with cover glasses exposed only to HBSS. Higher percentages of serum in the pretreatment solution resulted in even less attachment $(10,20$, and $40 \%$ serum resulted in $31.4,16.2$, and $10.8 \%$ attachment, respectively). The percentage of cells in the bipolar category (Fig. $1 c-e$ ) was not altered by this pretreatment of the glass surface.

The addition of CF to the cell suspension $60 \mathrm{~s}$ before injecting the cells into the chamber resulted in several changes in the counts. As can be seen in Table II, attachment of cells to albumin-treated glass increased significantly upon addition of $0.1 \mathrm{nM}$ f-Met-Phe though the percentage of bipolar forms was not different than control. The percentage of bipolar forms did increase significantly upon addition of $1 \mu \mathrm{M}$ f-Met-Phe. f-MetPhe, BCF, and C5a significantly increased attachment of PMN to serum-treated glass (Table II). The rate of
TABLE I

Effect of BSA and Serum on PMN Shape and Attachment to Glass

\begin{tabular}{lrcccc}
\hline Surface* & $n$ & $\begin{array}{c}\text { Bipolar } \\
\text { shapet }\end{array}$ & $P$ & Attachment $\$$ & $P$ \\
\hline & & $\%$ & & $\%$ & \\
Glass & 5 & $2.5 \pm 1.4$ & & $100 \pm 2.0$ & \\
BSA & 11 & $4.4 \pm 1.7$ & $>0.4$ & $49.2 \pm 4.8$ & $<0.001$ \\
Serum & 15 & $5.2 \pm 1.4$ & $>0.4$ & $43.3 \pm 3.5$ & $<0.001$ \\
\hline
\end{tabular}

* The glass coverslip in the slide chamber was pretreated by exposure to HBSS, BSA $(50 \mathrm{mg} / \mathrm{ml})$, or serum $(10 \%)$ for 2 min, and washed in two changes of HBSS. PMN were suspended in HBSS.

$\ddagger$ Mean percent \pm SEM showing the bipolar configuration at $500 \mathrm{~s}$ after injection into the chamber.

$\$$ Mean percent \pm SEM remaining attached to the surface 400 $s$ after inverting the slide chamber.

settling onto the surface was not altered, and there were no cell aggregates observed.

PMN washed twice in CMf HBSS and incubated in CMf HBSS for $30 \mathrm{~min}$ at room temperature were examined in the slide chambers. Attachment was the same as controls in HBSS when examined on untreated glass coverslips (attachment, $100 \%, n=5$ ). However, when examined on serum-coated glass, there was a significant difference in adhesiveness (Fig. 3). The

TABLE II

Effect of CF on Adhesiveness of PMN in Slide Chambers

\begin{tabular}{llrcc}
\hline \multicolumn{1}{c}{ CF* $^{*}$} & Surfacet & $n$ & Attachment $\S$ & $P^{*}$ \\
\hline $\begin{array}{l}\text { None } \\
\text { f-Met-Phe } \\
(0.1 \mathrm{nM})\end{array}$ & BSA & 6 & $55.7 \pm 9.5$ & \\
$\begin{array}{c}\text { f-Met-Phe } \\
(10 \mathrm{nM})\end{array}$ & BSA & 6 & $74.5 \pm 10.8$ & $<0.005$ \\
$\begin{array}{c}\text { f-Met-Phe } \\
(1 \mu \mathrm{M})\end{array}$ & BSA & 4 & $88.2 \pm 12.1$ & $<0.005$ \\
$\begin{array}{c}\text { None } \\
\text { f-Met-Phe } \\
(1 \mu \mathrm{M})\end{array}$ & Serum & 26 & $45.5 \pm 3.2$ & \\
$\begin{array}{c}\text { C5a }(26 \mu \mathrm{gg} \\
\text { protein/ml) }\end{array}$ & Serum & 15 & $74.9 \pm 5.0$ & $<0.001$ \\
BCF $(1: 1,000)$ & Serum & 12 & $60.9 \pm 5.5$ & $<0.001$ \\
\hline
\end{tabular}

* Added to cells suspended in HBSS 1 min before injection of cells into chamber.

\$ The glass coverslip in the slide chamber was pretreated by exposure to BSA $(50 \mathrm{mg} / \mathrm{ml})$ or serum $(10 \%)$ for two $\mathrm{min}$, and washed in two changes of HBSS. PMN were suspended in HBSS.

$\$$ Mean percent \pm SEM remaining attached to the surface.

" Compared with control. 


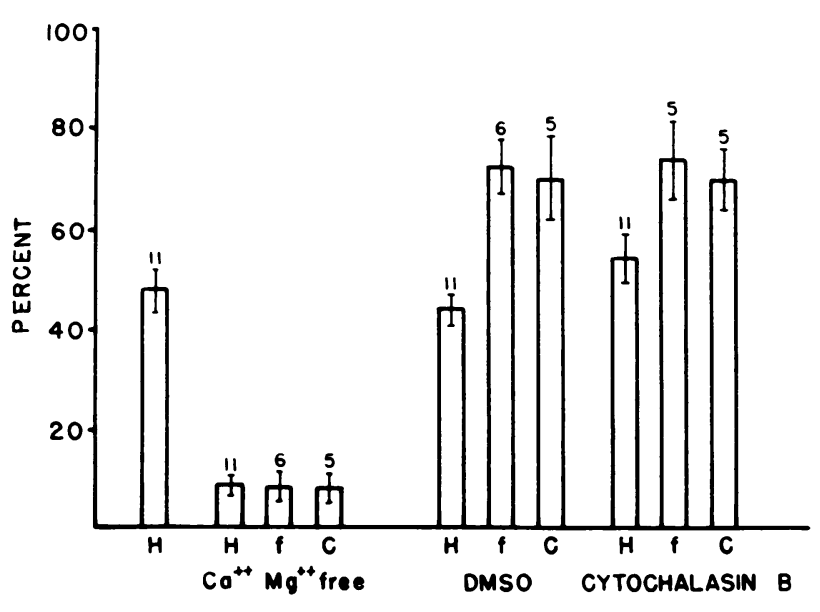

Figure 3 Attachment of PMN to serum-treated glass. "Percent" refers to the percentage of PMN remaining attached to the serum-treated glass. The results of four experimental conditions are given: PMN suspended in HBSS; PMN washed and suspended in CMf HBSS and then stimulated with CF; PMN exposed to $0.1 \%$ DMSO in HBSS and then stimulated with CF; and PMN exposed to $5 \mu \mathrm{g} / \mathrm{ml}$ cytochalasin B in HBSS for $10 \mathrm{~min}$ and then stimulated with CF. Numbers above each bar, number of experiments; brackets, \pm SEM. Abbreviations: H, HBSS; f, $1 \mu \mathrm{M}$ f-Met-Phe; C, $26 \mu \mathrm{g}$ protein/ ml C5a.

percentage of cells with a polarized shape was high $(92.8 \pm 4.1$ with $1 \mu \mathrm{M}$ f-Met-Phe and $94.7 \pm 3.8$ with 26 $\mu \mathrm{g}$ protein/ml C5a, $n=5$ ) and not significantly different from cells fixed in suspension. The addition of f-MetPhe or C5a did not enhance attachment in $\mathrm{Mg}^{++}$. deficient HBSS $(n=5, P>0.8$ ), but did enhance attachment in $\mathrm{Ca}^{++}$-deficient HBSS $(n=6, P<0.005)$.

Though pretreatment of PMN with cytochalasin B ( $5 \mu \mathrm{g} / \mathrm{ml}$ ) completely prevented the change in shape induced by addition of CF, this treatment did not change the level of attachment to serum-coated glass or the degree of enhanced attachment caused by addition of f-Met-Phe or C5a (Fig. 3). DMSO also did not affect attachment.

The reversibility of the enhanced adhesiveness was assessed by allowing cells to sit at room temperature for up to $45 \mathrm{~min}$ after removal of the CF. As can be seen in Table III, the enhancement induced by exposure to f-Met-Phe, ZAS, and C5a remained unchanged over this time even though the percentage of cells with a bipolar shape had decreased significantly from stimulated levels. In contrast, by $45 \mathrm{~min}$ the adhesiveness of PMN exposed to BCF was near that of controls.

Effect of preincubation in $C F$ on random motility. Table IV gives data on counts of cells migrating through filters of $5-\mu \mathrm{m}$-pore size. Lower counts were found for cells preincubated in ZAP, f-Met-Phe, or C5a. Table IV gives data on the track lengths of cells adherent to a glass surface. Cells preincubated in ZAP or f-Met-Phe showed very little migration during the observation period (10 min).

Restimulation of PMN: effects on chemotaxis. In the first group of these experiments, PMN were incubated for $30 \mathrm{~min}$ in HBSS containing ZAP, f-MetPhe, C5a, or BCF. The cells were then washed in HBSS and resuspended in HBSS containing $10 \%$ autologous plasma or $2 \%$ BSA. Within $15-30 \mathrm{~min}$ after removal of the CF the cells were placed in the blindwell chambers. Chemotactic activity was measured by counting the number of PMN on the lower surface of the filter at the end of a 3-h incubation. The cell counts were less for cells preincubated in $10 \%$ or $5 \% \mathrm{ZAP}, 0.1 \mathrm{mM}-0.1 \mathrm{nM}$ f-Met-Phe, or $10-35 \mu \mathrm{g}$ protein $/ \mathrm{ml}$ C5a. Maximum reduction occurred when PMN were preincubated in $10 \%$ ZAP, $10 \mu \mathrm{M}$ f-MetPhe, and $35 \mu \mathrm{g}$ protein $/ \mathrm{ml} \mathrm{C5a}$. C5a-pretreated cells gave a mean response of $34.9 \pm 3.7 \%$ of the response of cells preincubated in HBSS when C5a was the cytotaxin $(n=6, P<0.001)$; ZAP-pretreated cells gave 32.4 $\pm 8.2 \%$ of the control response to ZAP $(n=20, P$ $<0.001$ ); and f-Met-Phe-pretreated cells gave 16.8

TABLE III

Effect of Preincubation of PMN in CF on Adhesiveness in Slide Chambers

\begin{tabular}{|c|c|c|c|c|c|}
\hline Preincubation* & Surface & Time§ & $n$ & Attachment" & $P^{9}$ \\
\hline & & $\min$ & & $\%$ & \\
\hline $10 \%$ plasma & BSA & 15 & 4 & $31.7 \pm 1.6$ & \\
\hline $10 \%$ ZAP & BSA & 15 & 4 & $64.0 \pm 1.9$ & $<0.001$ \\
\hline HBSS & BSA & 15 & 5 & $63.7 \pm 3.7$ & \\
\hline $\begin{array}{r}\text { f-Met-Phe } \\
(10 \mu \mathrm{M})\end{array}$ & BSA & 15 & 5 & $99.0 \pm 0.5$ & $<0.001$ \\
\hline HBSS & Serum & 15 & 5 & $41.2 \pm 5.1$ & \\
\hline $\begin{array}{l}\text { HBSS } \\
\text { f-Met-Phe }\end{array}$ & Serum & 45 & 5 & $42.1 \pm 4.8$ & \\
\hline $\begin{array}{r}(10 \mu \mathrm{M}) \\
\text { f-Met-Phe }\end{array}$ & Serum & 15 & 5 & $73.4 \pm 5.2$ & $<0.001$ \\
\hline $\begin{array}{c}(10 \mu \mathrm{M}) \\
\mathrm{C5a}(26 \mu \mathrm{g}\end{array}$ & Serum & 45 & 6 & $75.3 \pm 4.1$ & $<0.001$ \\
\hline $\begin{array}{l}\text { protein } / \mathrm{ml}) \\
\text { C5a }(26 \mu \mathrm{g}\end{array}$ & Serum & 15 & 5 & $65.1 \pm 3.5$ & $<0.001$ \\
\hline protein/ml) & Serum & 45 & 6 & $75.5 \pm 4.7$ & $<0.001$ \\
\hline $\mathrm{BCF}(1: 500)$ & Serum & 15 & 4 & $91.3 \pm 4.4$ & $<0.001$ \\
\hline BCF (1:500) & Serum & 45 & 5 & $46.5 \pm 2.4$ & $>0.1$ \\
\hline
\end{tabular}

* $30 \mathrm{~min}$ at $37^{\circ} \mathrm{C}, 5 \% \mathrm{CO}_{2}$ in air, then washed and resuspended in $10 \%$ autologous plasma or HBSS.

t The glass coverslip in the slide chamber was pretreated by exposure to BSA $(50 \mathrm{mg} / \mathrm{ml})$ or serum (10\%) for $2 \mathrm{~min}$, and washed in two changes of HBSS. PMN were suspended in HBSS.

$\$$ AFter removal of the CF.

" Mean percent $\pm S E M$ remaining attached to the surface.

I Compared with control. 
TABLE IV

Effect of Preincubation of PMN in CF on PMN Migration

\begin{tabular}{lccccccccc}
\hline \multicolumn{1}{c}{ Preincubation* } & $n$ & $\begin{array}{c}\text { Leading } \\
\text { front }\end{array}$ & $P$ & $n$ & $\begin{array}{c}\text { Spontaneous } \\
\text { migration } \$\end{array}$ & $P$ & $n$ & $\begin{array}{c}\text { Track } \\
\text { length" }\end{array}$ & $P$ \\
\hline f-Met-Phe $(10 \mu \mathrm{M})$ & 5 & $22.0 \pm 5.9$ & $<0.01$ & 9 & $50.1 \pm 8.5$ & $<0.01$ & 4 & $25 \pm 3.0$ & $<0.01$ \\
C5a $(35 \mu$ protein/ml) & 4 & $24.7 \pm 5.7$ & $<0.02$ & 9 & $57.1 \pm 9.1$ & $<0.01$ & & & \\
$10 \%$ ZAS & 5 & $10.8 \pm 2.1$ & $<0.01$ & 4 & $35.7 \pm 4.9$ & $<0.01$ & 4 & $27 \pm 2.9$ & $<0.01$ \\
\hline
\end{tabular}

* Preincubation for $30 \mathrm{~min}$ at $37^{\circ} \mathrm{C}$, then washed twice in HBSS.

† Determined in 3 - $\mu \mathrm{m}$-pore size filters after $30 \mathrm{~min}$ in Boyden-type chambers. The cells were responding to the same $\mathrm{CF}$ as in the preincubation step. The value given is the mean difference in micrometers \pm SEM between the control (cells preincubated in HBSS or $10 \%$ serum) and the cells pretreated with CF.

$\$$ Determined by counting the number of cells accumulating on the lower surface of a filter (5- $\mu \mathrm{m}$-pore size) at the end of a 3-h incubation with no cytotaxin in the lower compartment of Boyden-type chambers. The value given is the mean percent \pm SEM of control (cells preincubated in HBSS or $10 \%$ serum) counts.

"Determined by measurements of track lengths of cells migrating on glass in a 10-min observation period. Includes all cells whether motile or not, and $>100$ cells were evaluated in each experiment. The value given is the mean difference in micrometers \pm SEM between the control (cells preincubated in HBSS or $10 \%$ serum) and cells preincubated in CF.

$\pm 3.9 \%$ of the control response to f-Met-Phe $(n=20$, $P<0.001$ ). The time course of preincubation required for this effect was tested for each factor. Preincubation in $10 \mu \mathrm{M}$ f-Met-Phe and $35 \mu \mathrm{g}$ protein/ml C5a for 10 min gave maximum depression of subsequent chemotaxis. Maximum effect of preincubation in 10\% ZAP did not occur until $45 \mathrm{~min}$.

Decreased counts $(P<0.02$ for each set of experimental conditions) also occurred when the pretreated cells were responding to $\mathrm{CF}$ other than the deactivating factor. PMN preincubated in $10 \%$ ZAP gave $46 \pm 10 \%$ $(n=4)$ of control counts when f-Met-Phe was the chemotactic stimulus, and $25.8 \pm 12 \%(n=4)$ when C5a was the stimulus. PMN preincubated in $10 \mu \mathrm{M}$ f-MetPhe resulted in $23 \pm 8 \%(n=4)$ when $\mathrm{ZAP}$ was the stimulus, and $39.7 \pm 15 \%(n=4)$ when $C 5$ a was the stimulus. PMN pretreated with $35 \mu \mathrm{g}$ protein $/ \mathrm{ml}$ C5a gave $49.9 \pm 5.3 \%(n=5)$ when ZAP was the stimulus and $51.8 \pm 8.9 \% \quad(n=5)$ when f-Met-Phe was the stimulus.

Preincubation in BCF (1:50-1:500 dilutions) did not significantly alter the response of PMN in chemotaxis chambers to BCF $(105 \pm 14 \%$ of the response of cells preincubated in HBSS, $n=4$ ), f-Met-Phe, C5a, or ZAS $(94.6 \%, 108 \%$, and $118 \%$, respectively, $n=3)$.

Restimulation of PMN: effects on cell shape and adhesiveness. Preincubations of PMN in CF were performed under conditions defined above. The PMN were washed twice and resuspended in HBSS and then restimulated at 15,45 , and $70 \mathrm{~min}$ after removal of the CF. Only PMN exposed to f-Met-Phe failed to respond to f-Met-Phe. All other experiments gave percentages of bipolar forms in suspension which were not significantly different from PMN preincubated under the same conditions in control solutions (HBSS or $10 \%$ serum) (Fig. 4). These results indicate that with the exception of f-Met-Phe, the preincubation in CF did not prevent the cells from "recognizing" and responding to a second chemotactic stimulus, and that the ability to respond as evidenced by a change in cellular shape was present from 15 to $70 \mathrm{~min}$ after removal of the initial stimulus.

A second exposure to CF did not significantly alter the level of attachment to serum-treated glass for PMN pretreated with f-Met-Phe, C5a, or ZAS. However, each restimulated adhesiveness in BCF-pretreated PMN (Table V). These effects on adhesiveness correspond to the observations in the Boyden chamber: Pretreatment of PMN with f-Met-Phe, C5a, and ZAS resulted in marked reduction in subsequent migratory response to the same or different CF, while pretreatment in BCF did not decrease subsequent chemotaxis.

\section{DISCUSSION}

Cellular polarity in neutrophils induced by CF. The data presented above support the idea that CF stimulate in neutrophils expression of an intrinsic cellular polarity which is not dependent upon a concentration gradient of $\mathrm{CF}$ or upon attachment of the cell to a surface. Our results show that human PMN are mostly spherical when isolated by the technique used in our study. When added to HBSS containing a CF, these spherical cells develop a polarized shape much like that seen in neutrophils migrating on a surface. The cells in suspension lack retraction fibers, however. The percent of bipolar cells varies with the concentration of the $\mathrm{CF}$, remains high for up to $60 \mathrm{~min}$ in its presence, 


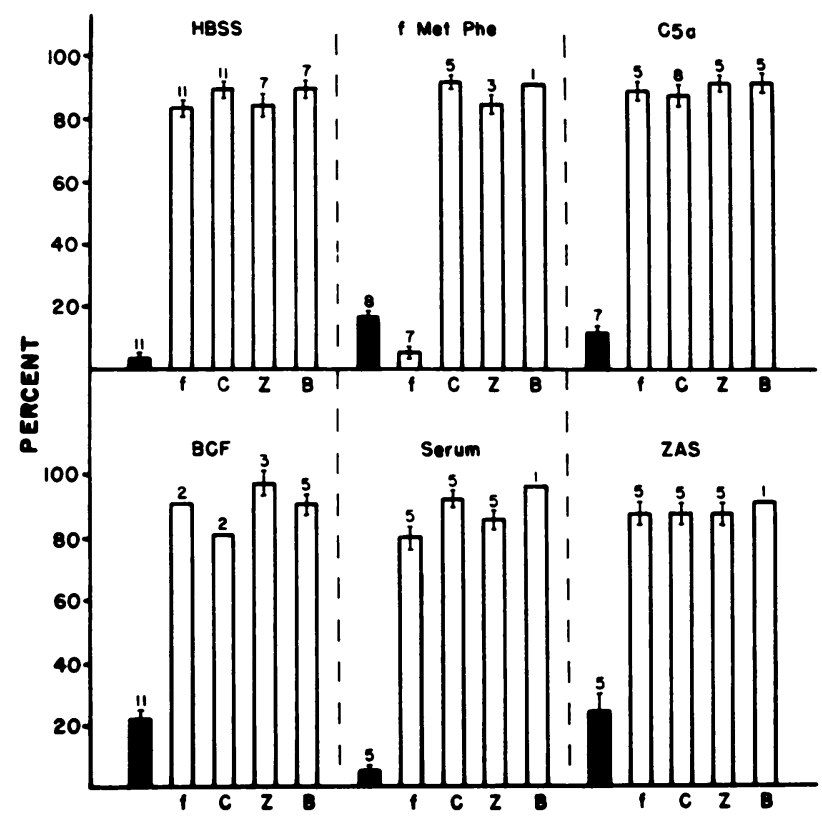

Figure 4 Change in shape of PMN exposed to CF. PMN were incubated in CF $(10 \mu \mathrm{M}$ f-Met-Phe, $35 \mu \mathrm{g}$ protein $/ \mathrm{ml}$ C5a, 1:50 BCF, or 10\% ZAS) or control solutions (HBSS or $10 \%$ serum) for $30 \mathrm{~min}$ at $37^{\circ} \mathrm{C}$ (the incubating solutions are listed above each group of 5 bars). The PMN were then washed twice in HBSS and allowed to sit for $45 \mathrm{~min}$ at room temperature. The cells were then re-exposed to CF (listed in abscissa) for $10 \mathrm{~min}$ and fixed in glutaraldehyde. The percentage of cells with a bipolar configuration was determined. Open bars give means $\pm S E M$ for $P M N$ restimulated with $C F$ and hatched bars give means \pm SEM for PMN without restimulation. Numbers above bars, number of experiments. Abbreviations: f, $1 \mu \mathrm{M}$ f-Met-Phe; C, $30 \mu \mathrm{g}$ protein $/ \mathrm{ml} \mathrm{C5a;} \mathrm{Z,} 10 \%$ ZAS; B, 1:500 BCF.

and falls to low levels by $15 \mathrm{~min}$ after its removal. The rapid occurrence of the change in cellular shape and the maintenance of a high response at low concentrations of cells suggest that it is a direct effect of CF on the cells,

TABLE V

Restimulation of Enhanced Adhesiveness of BCFPreincubated PMN*

\begin{tabular}{lccc}
\hline \multicolumn{1}{c}{ CF $\ddagger$} & $n$ & Attachment $\$$ & $P^{\sharp}$ \\
\hline & & $\%$ & \\
None & 5 & $47.2 \pm 2.9$ & \\
f-Met-Phe $(1 \mu \mathrm{M})$ & 5 & $79.2 \pm 4.9$ & $<0.001$ \\
C5a $(26 \mu$ grotein/ml) & 4 & $80.1 \pm 5.1$ & $<0.001$ \\
BCF $(1: 1,000)$ & 4 & $85.2 \pm 5.0$ & $<0.001$ \\
\hline
\end{tabular}

* PMN incubated $30 \mathrm{~min}$ at $37^{\circ} \mathrm{C}$ in 1:500 dilution of BCF then washed twice in HBSS.

$\ddagger$ Added to BCF pretreated cells 45 min after removal of BCF. $\$$ Mean percent \pm SEM remaining attached to serum-treated surface in slide chamber.

" Compared with control. not an effect secondary to factors released from PMN. The percentage of cells exhibiting the bipolar shape was consistently high for each CF and did not show much variation among donors or from day to day in the same donor. This consistency is in contrast to experience with the Boyden chemotaxis assay and the assessments of migration rates in neutrophils $(3,15)$.

The development of a polarized shape does not seem to depend upon contact of cells with a surface or with other cells. This idea is supported by the following observations: $(a)$ the technique for assessing the cell shape allowed for fixation of cells while in suspension; (b) the quick response minimized the opportunity for contact with the sides of the centrifuge tubes; $(c)$ the response was observed in viable cells in slide chambers before the cells settled onto the glass surface, and when cells were in CMf HBSS and allowed to settle onto serum-coated glass (a condition which markedly reduced sticking of cells contacting the glass); and $(d)$ cell aggregation $(16,17)$ seems an unlikely cause of the shape change because we did not find aggregation under the conditions of our experiments.

Factors affecting cellular adhesiveness. Our data are consistent with the observations that the pretreatment of glass with albumin or serum reduces attachment of neutrophils to the treated surface (18). Though the chemical basis for this effect is yet to be determined, we used the phenomenon to provide a controlled level of attachment of neutrophils to a surface. Thus, we did not apply a controlled force to detach the cells, and we could use a slide chamber for direct observation of the cells contacting the surface. This technique allowed confirmation of the conclusion made by others that the exposure of neutrophils to activated plasma (19) and f-Met peptides (17) increases their adhesiveness. Furthermore, we were able to show that a chemotactically active fraction of activated serum (C5a) as well as BCF produced significant enhancement of adhesiveness.

Adhesiveness and change in shape in response to a CF could be dissociated by four experimental conditions. (a) Adhesiveness to serum-treated glass was affected by $\mathrm{Mg}^{++}$levels in the medium; a finding consistent with the reports of others $(4,20-23)$. The enhancement of adhesiveness induced by $C F$ was not observed in $\mathrm{Mg}^{++}$-deficient medium while the percentage of bipolar forms was unchanged. Replacement of $\mathrm{Ca}^{++}$ in the CMf HBSS had no effect on levels of attachment or percent bipolar cells. (b) Cells treated with $5 \mu \mathrm{g} / \mathrm{ml}$ cytochalasin B appeared spherical with phase-contrast optics and have shown very few cytoplasmic projections when examined under scanning (11) and transmission electron microscopy (24). Their adhesiveness, however, and the degree of enhanced adhesiveness after exposure to CF, was the same as cells in HBSS and cells exposed to low concentrations of DMSO. (c) 
Adhesiveness remained high in neutrophils pretreated with C5a, f-Met-Phe, and ZAS at $\mathbf{4 5}$ min after removal of the cytotaxin: a time when most cells had returned to a spherical shape. (d) Exposure of neutrophils to 0.1 nM f-Met-Phe caused significant enhancement of adherence to BSA-coated glass. This concentration of $\mathrm{f}$ Met-Phe was below that necessary to induce a detectable change in cell shape.

Chemotactic deactivation and cell motility. Exposure of rabbit and human neutrophils to certain CF results in chemotactic deactivation $(25,26)$ (i.e., an apparent decrease in chemotactic responsiveness in the Boyden assay). Deactivation seems to be nonspecific as migration in response to factors other than the one used to pretreat the cells is significantly reduced. In our studies, human neutrophils were exposed to CF under conditions intended to induce deactivation. Confirmation of this phenomenon was obtained for C5a, f-MetPhe, and ZAS. Pretreatment of cells with BCF did not reduce the chemotactic response in Boyden assays, a finding consistent with previous studies (26). With one exception, deactivated neutrophils were able to change shape in response to a second chemotactic stimulus. The exception was with f-Met-Phe, which induced a specific unresponsiveness to restimulation with f-MetPhe. This observation seems to be consistent with those of Hatch et al. (27) and with the concept of a cell-associated receptor for f-Met peptides $(28,29)$. However, neutrophils pretreated with f-Met-Phe were quite responsive to the other CF. If the change in cell shape is a result of stimulation by a CF, then it seems that deactivated cells show reduced translocation, but have not lost the ability to sense a chemotactic stimulus. A reduced sensitivity to the stimulus was not obvious because the percentage of cells showing a change in cellular configuration after addition of a CF was not reduced by the deactivation step. In this regard, Goetzl and Austen (30) demonstrated normal stimulation of the hexose monophosphate shunt in deactivated PMN on re-exposure of CF (C5a or kallikrein), although the migration of the cells in a chemotactic gradient was reduced.

In contrast to the results concerning changes in cell shape, the enhanced adhesiveness induced by preincubation in C5a, ZAS, and f-Met-Phe did not diminish toward control levels after removal of the stimulus and was not altered by a second exposure to a CF. Thus, the conditions which produce deactivation also result in sustained enhanced adhesiveness. Pretreatment with BCF did not produce a sustained effect on cell attachment, nor did it produce deactivation. The nonspecific characteristics of chemotactic deactivation (cross-deactivation and decreased translocation in the absence of a chemotactic gradient) may therefore be causally linked to the sustained enhancement of adherence. An association of increased resistance to detachment and decreased migration has been observed in certain tissue cells $(5,6)$ and in macrophages exposed to lymphokines (31).

Several other observations indicate that alterations in neutrophil migration are associated with alterations in the cell-substratum interaction. (a) Albumin has a chemokinetic effect in the Boyden assay (32) and has been found by many investigators to be important in obtaining an effective chemotactic response. Albumin decreases neutrophil adherence to glass. (b) Deficiency of $\mathrm{Mg}^{++}$in the culture medium significantly reduces PMN migration in the Boyden assay $(13,33)$ and adhesiveness to protein-coated glass $(4,20-23)$. Neither effect is corrected by addition of extra $\mathrm{Ca}^{++}$. (c) Certain drugs which effect increases in intracellular cyclic AMP decrease PMN migration (1) and adherence to glass (34). (d) Exposure of the micropore filters to solutions of casein increases PMN migration in the Boyden assay (35). This effect is apparently a result of casein bound to the filter. Thus, it seems that interpretations of PMN migration in the Boyden assay must include consideration of the cell-substratum interaction.

Studies in vitro, such as the ones discussed above, indicate that $\mathbf{C F}$ influence neutrophil mobility in several ways depending upon the concentration of the factor and the mode of presentation to the cell. There may simply be a change in cellular shape not requiring attachment to a substratum or an enhancement of translocation expressed either as a polarized, but randomly directed, locomotion or as a directed migration in a gradient. There may be reduced migration via the mechanisms of deactivation. These mechanisms are unclear at present but, as indicated by our results, probably involve both saturation of receptor sites (e.g., as with f-Met peptides) and nonspecific changes in the mechanisms of cellular locomotion. Furthermore, neutrophils exhibit enhanced adhesiveness on exposure to CF under conditions which result in chemokinesis and in deactivation. This effect, if it occurs in vivo, may influence margination. Whether $C F$ enhance cellular adherence to a substratum when presented to the cell in a gradient remains to be tested. This possibility seems quite likely and may be a part of the mechanism of orientation in a gradient (1).

\section{ACKNOWLEDGMENTS}

This work was supported by National Institutes of Health grant AI 11367-03, and Michigan Heart Association grant 20676.

\section{REFERENCES}

1. Carter, S. B. 1965. Principles of cell motility: the direction of cell movement and cancer invasion. Nature (Lond.). 208: 1183-1187.

2. Stewart, G. J., P. R. Lynch, F. A. Reichle, W. G. M. Ritchie, A. Smith, and R. G. Schaub. 1977. The adhesion of leuko- 
cytes, erythrocytes, and noncellular material to the luminal surface of natural and artificial blood vessels in vivo. Ann. N. Y. Acad. Sci. 283: 179-207.

3. Ramsey, W. S. 1974. Leucocyte locomotion and chemotaxis. Antibiot. Chemother. (Basel). 19: 179-190.

4. Bryant, R. E., R. M. DesPrez, M. H. VanWay, and D. E. Rogers. 1966. Studies on human leukocyte motility. I. Effects of alterations in $\mathrm{pH}$, electrolyte concentration, and phagocytosis on leukocyte migration, adhesiveness, and aggregation. J. Exp. Med. 124: 483-499.

5. Gail, H. M., and C. W. Boone. 1972. Cell-substrate adhesivity: A determinant of cell motility. Exp. Cell Res. 70: $33-40$.

6. Harris, A. 1973. Behavior of cultured cells on substrata of variable adhesiveness. Exp. Cell Res. 77: 285-297.

7. Becker, E. L. 1977. Stimulated neutrophil locomotion. Chemokinesis and chemotaxis. Arch. Pathol. Lab. Med. 101: 509-513.

8. English, E., and B. R. Anderson. 1974. Single step separation of red blood cells, granulocytes, and mononuclear leukocytes on discontinuous density gradients of FicollHypaque. J. Immunol. Methods. 5: 249-257.

9. Smith, C. W., J. C. Hollers, E. Dupree, A. S. Goldman, and R. A. Lord. 1972. A serum inhibitor of leukotaxis in a child with recurrent infections. J. Lab. Clin. Med. 79: 878-885.

10. Lichtman, M. A., and R. I. Weed. 1972. Alteration of the cell periphery during granulocyte maturation: Relationship to cell function. Blood. 39: 301-316.

11. Lichtman, M. A., P. A. Santillo, E. A. Kearney, G. W. Roberts, and R. I. Weed. 1976. The shape and surface morphology of human leukocytes in vitro: effect of temperature, metabolic inhibitors and agents that influence membrane structure. Blood Cells. 2: 507-526.

12. Schiffmann, E., B. A. Corcoran, and S. M. Wahl. 1975. Nformylmethionyl peptides as chemoattractants for leucocytes. Proc. Nat. Acad. Sci. U. S. A. 72: 1059-1062.

13. Gallin, J. I., and A. S. Rosenthal. 1974. The regulatory role of divalent cations in human granulocyte chemotaxis. Evidence for an association between calcium exchanges and microtubule assembly. J. Cell Biol. 62: 594-609.

14. Zigmond, S. H., and J. G. Hirsch. 1973. Leukocyte locomotion and chemotaxis. New methods for evaluation, and demonstration of a cell-derived chemotactic factor. $J$. Exp. Med. 137: 387-410.

15. Wilkinson, P. C. 1974. Chemotaxis and Inflammation. Churchill Livingston, Edinburgh.

16. O'Flaherty, J. T., D. L. Kreutzer, H. J. Showell, and P. A. Ward. 1977. Influence of inhibitors of cellular function on chemotactic factor-induced neutrophil aggregation. J. Immunol. 119: 1751-1756.

17. O'Flaherty, J. T., D. L. Kreutzer, and P. A. Ward. 1978. Chemotactic factor influences on the aggregation, swelling, and foreign surface adhesiveness of human leukocytes. Am. J. Pathol. 90: 537-550.

18. Vroman, L., A. L. Adams, M. Klings, G. C. Fischer, P. C. Munoz, and R. P. Solensky. 1977. Reactions of formed elements of blood with plasma proteins at interfaces. Ann. N. Y. Acad. Sci. 283: 65-76.

19. Fehr, J. 1977. Complement as a mediator of granulocyte adherence and margination: studies based on the acute neutropenia of filtration leukapheresis. The Granulocyte:
Function and Clinical Utilization. T. J. Greenwalt and G. A. Jamieson, editors. Alan R. Liss, Inc., New York. 243-258.

20. Banks, D. C., and J. R. A. Mitchell. 1973. Leukocytes and thrombosis. II. Relationship between leukocyte behavior and divalent cations, sulphydryl groups, red cells and adenosine diphosphate. Thromb. Diath. Haemorrh. 30: 47-61.

21. Garvin, J. E. 1961. Factors affecting the adhesiveness of human leucocytes and platelets in vitro. J. Exp. Med. 114: $51-73$.

22. Kvarstein, B. 1969. Effects of proteins and inorganic ions on the adhesiveness of human leucocytes to glass beads. Scan. J. Clin. Lab. Invest. 24: 41-48.

23. Penny, R., D. A. G. Galton, J. T. Scott, and V. Eisen. 1966. Studies on neutrophil function I. Physiological and pharmacological aspects. Br. J. Haematol. 12: 623-645.

24. Hoffstein, S., I. M. Goldstein, and G. Weissmann. 1977. Role of microtubule assembly in lysosomal enzyme secretion from human polymorphonuclear leukocytes. J. Cell Biol. 73: 242-256.

25. Goetzl, E. J., and K. F. Austen. 1974. Active site chemotactic factors and the regulation of the human neutrophil chemotactic response. Antibiot. Chemother. (Basel). 19: 218-232.

26. Ward, P. A., and E. L. Becker. 1968. The deactivation of rabbit neutrophils by chemotactic factor and the nature of the activatable esterase. J. Exp. Med. 127: 693-709.

27. Hatch, G. E., D. E. Gardner, and D. B. Menzel. 1978. Chemiluminescence of phagocytic cells caused by $\mathrm{N}$ formylmethionyl peptides. J. Exp. Med. 147: 182-195.

28. Aswanikumar, S., B. Corcoran, E. Schiffmann, A. R. Day, R. J. Freer, H. J. Showell, E. L. Becker, and C. B. Pert. 1977. Demonstration of a receptor on rabbit neutrophils for chemotactic peptides. Biochem. Biophys. Res. Commun. 74: 810-817.

29. Williams, L. T., R. Snyderman, M. C. Pike, and R. J. Lefkowitz. 1977. Specific receptor sites for chemotactic peptides on human polymorphonuclear leukocytes. Proc. Natl. Acad. Sci. U. S. A. 74: 1204-1208.

30. Goetzl, E. J., and K. F. Austen. 1974. Stimulation of human neutrophil leukocyte aerobic glucose metabolism by purified chemotactic factors. J. Clin. Invest. 53: 591-599.

31. Weiss, L., and D. Glaves. 1975. Effects of migration inhibiting factor(s) on the in vitro detachment of macrophages. J. Immunol. 115: 1362-1365.

32. Wilkinson, P. C., and R. B. Allan. 1978. Assay systems for measuring leukocyte locomotion: an overview. Leukocyte Chemotaxis. J. I. Gallin and P. G. Quie, editors. Raven Press, New York. 1-23.

33. Becker, E. L., and H. J. Showell. 1972. The effect of $\mathrm{Ca}^{++}$ and $\mathrm{Mg}^{++}$on the chemotactic responsiveness and spontaneous motility of rabbit polymorphonuclear leukocytes. Z. Immunitaetsforsch. Allerg. Klin. Immunol. 143: $466-476$.

34. Bryant, R. E., and M. C. Sutcliffe. 1974. The effect of $3^{\prime}, 5^{\prime}-$ adenosine monophosphate on granulocyte adhesion. $J$. Clin. Invest. 54: 1241-1244.

35. Dierich, M. P., D. Wilhelmi, and G. Till. 1977. Essential role of surface-bound chemoattractant in leukocyte migration. Nature (Lond.). 270: 351-352. 